\title{
Perdas econômicas decorrentes da cetose subclínica em vacas leiteiras na região do Caparaó/ES
}

Matheus Cruz de Oliveira, Graziela Barioni", Layara Pestana Sarmento, Rômulo Dutra Uliana, Ítalo Câmara de Almeida, Aline Nunes Simões, Mayra Cardozo Mendes, Dirlei Molinari Donatele, Leonardo de Bruym Denadai

Centro de Ciências Agrárias e Engenharias, Universidade Federal do Espírito Santo (UFES), Vitória, ES, Brasil

*Autor correspondente

e-mail: grazibari@gmail.com

\section{Resumo}

A cetose é uma doença metabólica comum em vacas leiteiras durante o período de transição, caracterizada pelo aumento de corpos cetônicos no sangue, leite e urina. O balanço energético negativo, decorrente da alta demanda energética requerida no início da lactação, favorece a ocorrência da enfermidade. Entre os sinais clínicos estão alteração na composição do leite equeda direta na produção (aproximadamente 7\%), e alteração na fertilidade, com o aumento do intervalo entre partos. Já em estados mais avançados, os animais podem apresentar tremores musculares, convulsões, coma e até morte. Objetivou-se avaliar as perdas econômicas causadas diretamente pela presença da cetose nas vacas em lactação na região do Caparaó, no Espírito Santo. Esse projeto foi aprovado pelo Comitê de Ética no Uso de Animais (CEUA - UFES) sob número 003/2015. Foram avaliadas 70 propriedades de doze municípios (Alegre, Bom Jesus do Norte, Divino de São Lourenço, Dores do Rio Preto, Guaçuí, Jerônimo Monteiro, Ibatiba, Ibitirama, Irupi, Iúna, Muniz Freire e São José do Calçado). Analisou-se 872 vacas leiteiras mestiças em diferentes fases de lactação, com média de produção de leite de 11,85 L/vaca/dia. Para o diagnóstico dos animais com cetose, foi utilizado o teste bioquímico Ranbut Randox ${ }^{\circledR}$ para determinação do $\beta$-hidroxibutirato (BHB) em soro sanguíneo, sendo este o principal corpo cetônico analisado por apresentar altos níveis no sangue. Animais com níveis menores que $0,8 \mathrm{mmol} / \mathrm{L}$ foram considerados sadios, e animais com níveis iguais ou maiores que $0,8 \mathrm{mmol} / \mathrm{L}$ foram considerados com cetose subclínica. Do total de 872 de vacas analisadas, 604 (69,27\%) apresentaram-se saudáveis e 268 (30,73\%) foram diagnosticadas com cetose subclínica. A produção de leite de 309.996 L/mês seria a esperada para a região do Caparaó se nenhum animal estivesse doente, o que geraria uma arrecadação de $\mathrm{R} \$ 371.995,20$ /mês, considerando o valor de $\mathrm{R} \$ 1,20$ o litro. Como a perda direta na produção de leite pela cetose é cerca de 7\%, a região do Caparaó deixou de produzir 6.669,18 L/mês, deixando de arrecadar R\$8.003,02/mês. Concluímos que a ocorrência de cetose em vacas leiteiras encontra-se alta na 
região do Caparaó, causando danos ao rebanho de forma direta, reduzindo a produção de leite e, com isso, cusando prejuízos econômicos e afetando significativamente a renda dos produtores e sua qualidade de vida.

Apoio Financeiro: Fundação de Amparo à Pesquisa e Inovação do Espírito Santo (FAPES). 